\title{
Study of Local Wisdom on the Role of Culture in Maternal and Child Health in Ruteng Subdistrict, Manggarai District, Ntt Province
}

\author{
Bambang Dharwiyanto Putro, A.A. Ayu Murniasih \\ Anthropology Study Program, Faculty of Arts \\ Udayana University \\ Denpasar, Bali \\ dharwiyantoputro@yahoo.com
}

\begin{abstract}
Health problems are closely related to culture or tradition in society. Cultural values in the community of Manggarai is a cultural potential that can be used as a means of agreeing to various public health issues including finding solutions to problems in the field of maternal and child health. Until now, traditional cultural values (local wisdom) still play important role in the process of maternal and child health care in the practice of pregnancy and childbirth care, and some are still handled by a traditional midwife (ata pecing). This study aims at determining the role of culture in maternal and child health practices, how health care search behavior and cultural potential of maternal and child health care practices in Ruteng sub-district are. The study was conducted by using an ethnographic approach method as one of the variants of the qualitative approach. The research activities included field assessments to understand the condition of the research location, field data collection by using interview, observation, literature and document verification techniques. The data collected from various sources were then processed, analyzed, and then presented in the form of interpretative descriptive argumentation. Manggarai community still believes in local customs and some particular behaviors for pregnant and postpartum women. A cultural conception of abstinence is intended to safeguard the safety of the mother and baby. However, the reasons revealed related to the restrictions are only symbolic. Health care providers and health workers need to understand the symbolic meaning contained in the respective abstinence.
\end{abstract}

Keywords: local wisdom, abstinence, culture, health

\section{BACKGROUND}

Indonesia consisting of thousands of large and small islands inhabited by hundreds of ethnic groups with various cultures has given its own distinctiveness. The behavior of the community, especially the traditional communities in the practice of maternal and child health care, is reflected in the utilization of intellectual property of local communities in the form of traditional knowledge and biodiversity in the environment. Cultural practices related to health are partly claimed by "modern" knowledgeable people as one of the causes of the poor health status of the local community. The cultural richness of Indonesia consisting of various ethnic groups scattered throughout Indonesia has colored the health efforts. Such health efforts can form conventional or traditional and complementary services in the form of preventive, promotive, curative and rehabilitative activities. The health services include community-based health services such as treatment and traditional methods.

The Maternal and Child Health Program (KIA) becomes a top priority for the Indonesian Public Health Development Program. Based on the results of the Indonesian Demographic Health Survey (IDHS) in 2007, the maternal mortality rate (AKI) in Indonesia was 228 per 100,000 live births, while the maternal mortality rate in East Nusa Tenggara Province (NTT) in 2010 reached 270 per 100,000 live births. In addition, Indonesian Infant Mortality Rate (AKB) in 2007 reached 34 per 1,000 live births, while in NTT Province reached 57 per 1,000 live births (NTT Health Office, 2010). In addition, the 
low public health indicator in NTT Province as illustrated by the Community Health Development Index (IPKM) in 2010 indicating that Manggarai district ranked $437^{\text {th }}$ nationally (Health Research and Development, 2010) is a separate note for NTT Province (Bangun, 2010). Based on a report from the Manggarai Health Agency in 2010, the maternal mortality rate in Manggarai district was 169.9 per 100,000 live births while the Infant Mortality Rate (AKB) was 13.20 per 1,000 live births. In addition, the coverage of childbirth assistance by health workers in 2010 was 76.25 percent, and delivery assistance by the traditional midwife was 23.75 percent. As of January-June 2016, the maternal and infant mortality rates in Manggarai District reached 31 cases.

The NTT provincial government, since 2009 has launched the Maternal and Child Health (KIA) revolution program intended to reduce maternal and infant mortality rates with one of the strategies implemented, is that all mothers giving birth are assisted by professionals at the public health center. But until now, the role of traditional cultural values in the process of maternal and child health care, especially in the practice of prenatal care and childbirth, is still handled by a traditional midwife. Health problems are closely related to culture or tradition in society. Cultural values in the Manggarai people are cultural potential that can be used as a means of agreeing on various public health issues including finding solutions to problems in the field of maternal and child health, so it is necessary and important to feature local wisdom into one of the ways to resolve cultural-based health problems in the community. On this basis, the research was conducted to determine the role of culture in maternal and child health practices and health care search behavior as well as the cultural potential of maternal and child health care practices in Ruteng sub-district.

\section{RESEARCH METHOD}

The design of this study uses a qualitative method that gives emphasis on the emic, ethical, holistic and deep description based on intensive field research about the role of culture in the practice of maternal and child health care in the frame of local wisdom and did not measure or examine as in the quantitative methods.

This research was conducted in Ruteng Pu'u kampong, Golo Dukal village, Langke Rembong subdistrict, Manggarai district, East Nusa Tenggara, with consideration, that among others, public health indicators in NTT Province from the Community Health Development Index (IPKM) in 2010 showed that Manggarai District was ranked $437^{\text {th }}$ nationally (Litbangkes, 2010) that became a separate note for the NTT Province (Build, 2010). Based on the reports from the Manggarai Health Office in 2010, the maternal mortality rate (AKI) in Manggarai district was 169.9 per 100,000 live births while infant mortality rate (AKB) was 13.20 per 1,000 live births. In addition, the coverage of childbirth assistance by health workers in 2010 was 76.25 percent, and delivery assistance by the traditional midwife was 23.75 percent. The Town Public Health Center (Puskesmas) located in Ruteng (the capital of Manggarai district) has the highest number of maternal mortality cases in 2010 . The main research instrument is the researcher himself, equipped with interview guidelines (interview guide) to assist in directing the course of the interview, then recording device, cameras, and stationeries.

Method of Data Collection--Observations are made to observe and examine factual facts in daily activities, especially in the practice of health care carried out by housewives that already have own children and/or housewives that will have children (pregnant women).

In-depth Interview Method--The use of in-depth interview techniques aims to explore a variety of information from informants regarding the attitudes, experiences, including exploring the hidden things (overt and covert behavior) related to research problems.

Methods of Individual Life History--This individual life history technique is carried out specifically for selected informants (pregnant women) in an effort to obtain information about the role of culture in maternal and child health practices in the frame of local wisdom and to find out how they make adjustments to socio-cultural factors that influence the process and the meaning.

Data analysis method--Data analysis was carried out descriptively and qualitatively. The data obtained need to be criticized and classified based on cultural assumptions and with a flexible, reflective and objective attitude (Endraswara, 2003: 15).

\section{RESULTS AND DISCUSSION}

a. The Role of Culture in Maternal and Child Health Practices During Pre-pregnancy Period

(Adolescence)

According to Ahmadi (2005: 105), the development of behavior in adolescence is characterized by the changes due to puberty, among others, the development of (cognitive) mindset of the adolescents, socio-emotional development of adolescents, and adolescent sexual development. Adolescence is quite different between women and men in terms of knowledge and values learned about reproductive health. Reproductive health lessons are obtained at school in biology subject and from peer groups that tell each other about their experiences, the opposite sex, reproduction, menstruation, and so on.

Results of the field research showed that among adolescents in Ruteng Pu'u village, dating is not a 
taboo thing. Nevertheless, in social norms, there are still limitations in terms of the association between teenage boys and girls. These limitations include not being alone, especially in quiet places, not disturbing women, not holding a woman's hand or shoulder.

\section{b. Knowledge of Adolescent Reproductive Health System}

Related to the Knowledge of the Adolescent Reproductive Health System, the information is obtained, among others, from parents (mothers), siblings and the school. Nevertheless, adolescents claimed to have inadequate knowledge in the field of reproductive organ systems. During that phase, they are believed to experience uncontrollable emotions. Therefore, they should attempt to control emotions as well as possible and maintain themselves because a woman is analogized to be a glass plate where once it falls and breaks it will not be able to return to normal.

\section{c. Abstinences during Pre-Pregnancy}

Related to restrictions in the pre-pregnancy period, informants stated that they are not allowed to drink alcoholic beverages (neka inung tuak), smoke (neka rongko), go out at night (neka lako wie), and be together in a quiet and dark place (neka cumang, sua tau lewie). In the case of customary rules during the pre-pregnancy period, customary leader of Ruteng Pu'u village, Maximus Antar, explained some rules that must be obeyed as follows:

Firstly, mancak tara nggelok weki (charming face). A man when having a sense of love with a girl and wants to marry her, the first thing to do is telling her parents that he wants to marry the woman. If there is approval from parents, do the next step.

Secondly, Lambung mbaru or visiting the house is carried out by man's side along with his parents to apply for their ideal girl by visiting the girl's house. By and large, this is done at night. Night time is selected to avoid obstacles such as the family of the woman remains to work in their garden and other villagers do not know about it. When arriving at the woman's home, they will be invited to sit down or chat friendly.

Thirdly, Towe Tabing (proposing songket cloth) - provision of songket cloth by man's side to women is accompanied by his family while saying "amang agu inang neka rabo mai daku lambung mbaru dite ae aku manga mena mata agu anak dite, ho'o towe latang wengko de enu"(Dear uncle and auntie, I and my parents come here with the intention to propose your daughter, this cloth is a symbol of my seriousness') while handing over the songket cloth to the parents of prospective bride as the seriousness of the bridegroom. If the songket cloth is accepted by a woman's family, here is the next step.

Fourthly, keepsake (bond) - this is done a week after the "towe tabing," (proposing cloth) this activity is usually filled with ring exchanges and witnessed by the parents or their respective proxy as a sign of the bond of love, as well as asking for the blessing from the woman' parents or female proxy asks about the amount of dowry or "cumang cama tua" (dissemination of belis money by parents of women and men). After getting an agreement or the "pongo" can have been determined, it is resumed with the following step.

Fifthly, Wagal (carrying a dowry) — having had an agreement or deals regarding the number of dowries, the "Wagal" (carrying a dowry) is not carried out on an auspicious day but depends on the agreement between both parties.

\section{d. Pregnancy Period (Na'ang Weki) People's View on Pregnancy \\ Pregnancy is a period when a pregnant woman} undergoes the initial process of pregnancy until nearing birth. During pregnancy, she generally makes checkup on a regular basis every month at the Golo Dukal Health Center. Most informants stated that pregnancy is a gift and a blessing to be grateful for. If they are pregnant, they will be delighted and feel happy. Pregnancy is a part of the life cycles. In particular communities, it gets special attention through the implementation of certain rituals. However, this matter is different from the one found at Ruteng Pu'u village. There is no ritual whatsoever during a mother's pregnancy, but there is only a tradition of going to "Father" to ask for prayers.

\section{e. Abstinence Applying in Society during Pregnancy}

During pregnancy, housewives at Ruteng Pu'u village are not allowed to do the following activities: a) doing heavy work / lifting heavy burdens (neka seti sot mendo-mendo); b) drinking alcohol (neka inung tuak); c) consuming raw eggs (neka hang ruha ta'a); d) going out at night starting from 7 o'clock (neka lako wie at 7); e) saying harshly (neka curup $d a^{\prime} a t$ ); f) weaving (to avoid cervix from getting narrow when giving birth); g) using cutlery from the pot cover (neka hang oake todu lewing); and h) consuming the remaining rice from the cooking pot, meaning that when giving birth she will not have feces (neka hang rateng). Pregnant women also adhere to other applicable taboos, such as forbidden from bathing at night, killing animals, weaving, having a seat at the doorstep, and going to the river or water source in the afternoon. If the abstinence is still disobeyed, the birth process is believed to be problematic or the baby will be born imperfectly.

\section{f. The Role of Husband in Pregnancy Care}

During pregnancy care phase, the roles of husband found at Ruteng Pu'u village can be said to remain inadequate (not optimal). For instance, some of the findings are as follows: (1) not all husbands can fulfill what their wife wants when they are craving; (2) field data indicated there is no sexual 
intercourse made after finding out if the wife had been positively pregnant; (3) the involvement of husband only happens in particular times in assisting domestic works such as washing clothes, cooking, helping to buy food ingredients; (4) the husband occasionally helps take care of the elder son or daughter; (5) the husband occasionally accompanies his wife to check up to public health center.

\section{g. Childbirth}

Childbirth is a condition that needs special attention considering that during the period there is a very high risk for the occurrence of a critical condition that can endanger a mother's life. The people of Ruteng Pu'u village are aware of this risk. It is evidenced by the preventive efforts carried out in the form of both medical and non-medical measures. In addition to physical preparation, they also carry out psychological preparations, which are made by both the mother and the family, and there is even a lot of support from the environment.

\section{h. Post-Childbirth}

A number of measures are carried out to help childbirth process. Non-medical measure, for instance, is a provision of drinking water with mantra given by traditional midwife (ata pecing) with the hope that the childbirth process can run smoothly. Meanwhile, in terms of medical perspective or based on modern science (Kleinman, 1980: 104-118), the measures taken are by preparing equipment such as infusion, oxygen, baby baths, buckets, scissors, sterile gloves, baby bed, cardiotocography (KTG). The measures after the childbirth process include the non-medical or customary preparation, namely:

Ongga rinding (hitting the wall)--When a new baby is born, the father or grandfather of the baby that guards outside the house will hit the wall of the house for five times while saying ata one ko ata peang (an insider or an outsider). If the newborn baby is a male, the mother who helps give birth will answer ata one (insider), if the baby is female, she will say ata peang (outsider).

Poro putes (cutting baby's umbilical cord)--The tool used to cut the baby's umbilical cord is lampek (bamboo blade) totaling five pieces because according to the Manggarai people's belief, there are five aspects of life that must be passed through by the Manggarai people from their birth to their return or passing away. They consist of 1) house as a place to live (Mbaru bate kaeng); 2) playground (natas bate labar); 3) water as a source of life (wae bate teku); 4) workplace or livelihood system (uma bate duat); 5) the grave or the last aspect of death (boa). After cutting the umbilical cord, it is resumed with the next step.

Cumpe (baby bed)--After being born, a baby remains to stay with its mother in the room beside the fireplace having been designed in such a way for five days and five nights. Cear cumpe (unloading baby bed), that is, after five days and five nights in the cumpe (baby bed); on the fifth day, the cumpe will be dismantled. After that, it is resumed with teing ngasang (naming). In the tradition of Manggarai, during the naming ceremony, there are two kinds of naming namely the traditional name or in the Manggarai tradition, it is often called ngasang manuk. Commonly, the name used is taken from their ancestors of the family concerned, such as Ngabut, Haman, Jebarus et cetera, and the second is baptism name or ngasang serani. By and large, the baptism name in use is of the patron saints such as St. Aloysius, Santa Maria et cetera. The naming process does not choose an auspicious day but is determined after ending the five days and five nights.

From a medical standpoint, among others, they clean up the mother's blood and amniotic fluid, cut the umbilical cord by using sterilized scissors as well as give medicine in the form of alcohol, Betadine (antiseptics) on the baby's umbilical cord having been cut. Afterward, they bathe the baby by washing it clean.

i. Breastfeeding Stage (teing wae cucu) Knowledge of the Importance of Breastfeeding

Special habits that people do when breastfeeding are consuming certain foods and vegetables like cassava leaves and fruits and bananas in larger quantities. This method is believed to produce more breast milk so that the baby gets good nutrition. In this case, the mother whose breast milk does not go out will give a massage to the breasts with her hands so that it quickly comes out. There is a belief in breastfeeding mothers that with frequent breastfeeding taken by the baby it will stimulate the amount of breast milk produced.

\section{j. Abstinence while Breastfeeding Stage}

Related to restrictions in the stage of breastfeeding, there is information obtained as follows: the mother is forbidden to eat spicy foods (benang hang mas), drink alcoholic beverages (benang inung tuak) and smoke (neka rongko). On the contrary, she is recommended to breastfeed until the baby reaches 2 years old and avoids excessive stress because it will affect her breast milk production.

\section{k. Knowledge Source of Baby's Umbilical Cord Care}

Sources of knowledge about traditional care for newborns are obtained from village midwives in charge of the public health center or medical teams and parents as well as the experiences of neighbors that have given birth. In this case, the role of people always teaches about what should and should not be done. More of this knowledge is obtained from parents considered to have advantages in baby treatment and care. 
1. Knowledge of Baby's Umbilical Cord Care

From a medical point of view, the cutting of the umbilical cord is by using sterile scissors, giving medicine in the form of alcohol and Betadine on the baby's umbilical cord that has been cut. In nonmedical point of view, people apply turmeric or betel leaves to the former umbilical cord cut.

\section{m. Tradition while in Baby Period}

The tradition applied while in baby period is the making of baby bed or cumpe along with its mother for five days and five nights. Then, it is resumed with visiting the newborn baby or la'at meka weru. After the process of childbirth is over, the family immediately prepares a heating furnace placed close to the baby bed so that the baby can get warmth from the coals of the wood in the furnace. To provide warmth for the baby, its mother will place her hand near the embers, and then rub the baby's body. This practice is mostly carried out in the morning and evening when the air is cold. Five days later, from one day after the birth, the baby's family will hold a cear cumpe event, namely the procession of separating the heating furnace from the baby's bed. When holding the cear cumpe, the parties invited to attend the event are representatives of the anak-ronaanak wina, ase kae, ase-kae-beo (big family of the village) as well as those who have helped the childbirth process.

n. Health/Medical Treatment Behavior Reasons for Choosing Formal Health Services

From the results of interview, it was obtained information that mothers choose subsidiary public health center to get health checkup or treatment because it is very close to their home, and the services are very good where they are always given counseling in order to always take care of our health through daily activities such as regular meals, regular exercise, consuming nutritious foods such as rice, vegetables, meat, and fruits, or side dishes and water.

\section{o. Non-Formal Health Services}

Related to the selection of non-formal health services according to the informants, it is suggested by their families to eat a lot and not to work too hard. Besides, they are recommended to always wake up early, and drink water having been prayed by a traditional midwife (ata pecing), and drink blessed water from the local priest. It aims to maintain the health of the soul and body of the mother and baby and to put on narong to avoid evil spirits because the smell of narong is very prominent. According to local belief, the evil spirits do not like the smell of narong.

The information obtained from several village midwives at the Golo Dukal health center stated that currently traditional midwife (ata pecing) only delivers and accompanies delivery in the subsidiary public health center. When accompanying childbirth in the subsidiary public health center, traditional midwife (ata pecing) gives water and oil having been prayed to be drunk by the mother that will give birth. This aims to make it easier and there will be no obstacles during childbirth. After giving birth, the traditional midwife does not clean the baby because it will be bathed at home only after 6 hours. There are charges for each traditional midwife for escorting a mother to the subsidiary public health center at IDR 50,000.00 per person.

\section{p. Reasons for Choosing Non-Formal Health Services}

Regarding the reasons for choosing non-formal health services, one of the informants stated that provision of treatment by the traditional midwife (ata pecing) like drinking water having been prayed by the traditional midwife and blessed water from the priest is meant to help the childbirth run more smoothly.

\section{q. Cultural Potential of Maternal and Child Health Community Organization System}

The community organization system at Ruteng $\mathrm{Pu}$ 'u village can be said to be a manifestation of adherence to indigenous leaders. A few people live in groups around the gendang house because they consider it comfortable when living close to the gendang house. Gendang house is a traditional house of the Manggarai community which generally has a drum (a musical instrument) in it. This drum functions as a symbol of leadership so that if mentioning the word drum, it can lead to the meaning of coverage of the area under the arrangement of the drum house.

Etymologically, the gendang is a kind of traditional musical instrument of Manggarai. In essence, it is an institution of authority from a customary law community. Functions, tasks and organizational structure of the Gendang in Manggarai are the same, namely: (1) upholding the history of the lineage; (2) maintaining the gendang leadership; (3) uniting gendang residents; (4) arranging the social life of the gendang people; (5) maintaining land ownership and regulating its distribution; and (6) form a strong defense against the enemy.

\section{r. Religious Aspects}

Religious aspect serves as a medium for delivering messages or promoting the delivery of health programs. By and large, religious leaders or pastors will forbid people from getting married if the couple is of the same blood (Tungku Cu or Tung Dungka), namely the marriage between the son of the mothers and the daughters of her sister or uncle. s. Knowledge of Traditional Medicines and
Traditional Methods 
There is knowledge about traditional medicines, such as coconut oil. Coconut oil is used to provide massage as well as betel leaves to speed up the drying of wound and others. The knowledge is obtained from their ancestors, inherited from generation to generation until these days.

t. Certain Restrictions Related to Food for Pregnant Women

The restrictions applied to mothers during their pregnancy, among others, include not doing heavy work / taking up heavy burden (neka seti sot mendomendo), not drinking alcoholic beverages (neka inung tuak), not consuming raw eggs (neka hang ruha ta'a), not going out at night starting from 7 o'clock (neka lako wie jam 7), not saying harshly (neka curup da'at), not weaving (to avoid cervix from getting narrower during childbirth), not using cutlery from pot cover (neka hang oake tadu lewing), and not consuming the rest of rice from the cooking pot, meaning to prevent from having feces when giving birth (neka hang rateng).

Of these restrictions, pregnant women also adhere to other applicable taboos or restrictions, such as they are not allowed to bathe at night, kill animals, weave, have a sit at the door and go out to the river or source water in the afternoon. If the abstinence remains to be violated, the childbirth process is believed to be problematic or the baby is born imperfectly.

\section{CONCLUSION}

Customs or cultural procedures in the community's life of Ruteng Pu'u kampong, Golo Dukal village, Langke Rembong subdistrict, Manggarai district, East Nusa Tenggara has followed the development of modernization. Nevertheless, traditional culture remains to exist and is not abandoned. One the one hand, the community believes in modern methods of treatment, but on the other hand, they are proven to continuously use and practice traditional methods in the matter of maternal and child health care in the context of local cultural wisdom staying inherent and well maintained.

This social life regulation is entirely set forth in the values of local customs that must still be maintained because they have a positive impact. Ethical issues of adolescence, courtesy ethics, taboo problems, abstinence in pre-pregnancy, pregnancy and post-pregnancy period are all values of the society that are maintained and developed.

\section{EXPRESSIONS OF GRATITUDE}

Researcher realizes that this research can be implemented on account of the help and encouragement of various parties. On that account, through this opportunity, the researcher would like express profound gratitude to Chairperson of the
Udayana University's Research and Community Service Institute (LPPM) and the Dean of the Faculty of Humanities of the Udayana University that has approved and supported this research funding through the Study Program's flagship funding scheme. Similar thanks are also delivered to the Traditional Elders of Ruteng Pu'u village, the headman of Golo Dukal, the traditional midwives and village midwives, the mothers and teenagers of Ruteng Pu'u village, and others that researchers cannot mention one by one. A sincere tribute is also extended here for their help and goodness so that this research can run well. Likewise, the researcher thanks other parties who have helped smooth this research.

\section{REFERENCES}

[1] Ahmadi \& Sholeh, 2005. Psikologi Perkembangan. Jakarta: PT. Rineka Cipta

[2] Bangun, Rikard., 2011. Ekspedisi Jejak Peradaban NTT. Laporan Jurnalistik Kompas, Jakarta.

[3] Dinkes Kabupaten Manggarai. 2010. Profil Kesehatan Kabupaten Manggarai. Ruteng.

[4] Dinkes Provinsi NTT. 2010. Pedoman Revolusi Kesehatan Ibu dan Anak. Kupang.

[5] Dinas Kesehatan Provinsi Nusa Tenggara Timur. 2009. Profil Kesehatan NTT 2009, Kupang.

[6] Dinas Kesehatan Provinsi Nusa Tenggara Timur. 2010.Laporan Seksi KIA 2010, Kupang.

[7] Dinas Kesehatan Kabupaten Manggarai. 2010. Profil Puskemas Narang 2010, Manggarai, Ruteng.

[8] Endraswara, Suwardi. 2003. Metodologi Penelitian Sastra. Yogyakarta: Pustaka Widyatama.

[9] Dinas Kesehatan Provcinsi Nusa Tenggara Timur., 2010. Pedoman Teknis pelaksanaan Desa Siaga di Provinsi NTT. Kupang.

[10] Indeks Pembangunan Kesehatan Masyarakat., 2010. Badan Penelitian dan Pengembagan Kesehatan (Balitbangkes) Kementerian Kesehatan RI., Jakarta.

[11] Kleinman,1980. Patients and Healers in the Context of Culture: An Exploration of the Borderland between Anthropology, Medicine, and Psychiatry. Los Angeles London: University of California Press Berkeley. 